\title{
Synthesis and Nitration of 7-Hydroxy-4-Methyl Coumarin via Pechmann Condensation Using Eco-Friendly Medias
}

\author{
Fadia Al-Haj Hussien ${ }^{1}$, Mohammad Keshe ${ }^{1}$, Khaled Alzobar ${ }^{1}$, \\ Joumaa Merza ${ }^{1}$, Ayman Karam $^{2,}$ \\ ${ }^{1}$ Department of Chemistry, Faculty of Sciences, University of Al- Baath Homs, Syria. \\ 2,* Institut de Chimie des Milieux et Matériaux de Poitiers, CNRS, Université de Poitiers/ENSIP, \\ 1 rue Marcel Doré, 86073 Poitiers Cedex, France.
}

E-mail: ayman.karam@univ-poitiers.fr.

Keywords: Pechmann Condensation, Coumarin, Eco-Friendly Medias.

\begin{abstract}
A nitro coumarin derivatives have been synthesized via nitration of 7-hydroxy-4-methyl coumarin which was synthesized via Pechmann condensation resorcinol with a $\beta$-ketoester using Amberlyst-15 as a green and efficient catalyst and by caring out the reaction of resorcinol and ethyl acetoacetate (with 1:1 mol ratio) in the presence of $0.2 \mathrm{~g}$ of Amberlyst- 15 at $110^{\circ} \mathrm{C}$ under solventfree conditions. These nitro coumarin derivatives have biological activity and momentousness in the industrial fields. The purified products were determined the melting points and characterized by spectral methods: FT-IR, ${ }^{1} \mathrm{H}-\mathrm{NMR},{ }^{13} \mathrm{C}-\mathrm{NMR}$.
\end{abstract}

\section{INTRODUCTION:}

Coumarins are an important class of organic compounds occurring widely in nature. Synthesis of these compounds by simple methods is being attempted because of a wide variety of uses such as fixatives in food and cosmetics, liquid crystal displays, information systems, pharmaceuticals, insecticides, rodenticides and to mask disagreeable odors in industrial products such as printing inks, paints and synthetic rubber [1-7].<smiles>O=c1ccc2ccccc2o1</smiles>

Figure 1. The basic structure of Coumarins.

Coumarin (2H-1-benzopyran-2-one) is synthesized via Perkin reaction by refluxing a mixture of salicylaldehyde and acetic acid in the presence of anhydrous sodium acetate and cobaltous chloride hexahydrate [8] and by the condensation of salicylaldehyde with acetic anhydride in the presence of a base catalyst trimethylamine [9]. Knoevenagel [10], Witting [11], Reformatsky [12], Claisen rearrangement [13], Michael condensation [14] and Pechmann reaction [15] are also employed in the synthesis of coumarins. Recently, Knoevanagel condensation is reported to proceed with high selectivity and reactivity in the formation of coumarins over solid base catalysts [16]. Microwave irradiation accelerates these reactions several-fold with better yields of the products where the reactants, however, are taken in millimoles quantities [17, 18]. Some important coumarins have been synthesized in 1-butyl pyridinium chloroaluminate ionic liquid in good yields [19] and also in indium (III) chloride [20]. Some of the industrially important coumarins such as 7- hydroxy-4-methylcoumarin are prepared via Pechmann reaction by the condensation of a phenol with $\beta$-ketoesters in acidic medium [21].

The conventional acids such as sulfuric acid, aluminum chloride, phosphorus oxychloride, polyphosphoric acid, etc., that are used for catalyzing this reaction are hazardous and cannot be recovered. Hence, solid acids such as zeokarb 225, IRC- 20 [22], modified Y zeolites [23], zeolite H- $\beta$, Filtrol (acid clay) [24] and K-10 montmorillonite 6 clay were used in the synthesis of 7-hydroxy-4-methylcoumarin from resorcinol and ethyl acetoacetate. These heterogeneous reactions have simple process of product isolation. In all these processes, however, the mixture of 
phenol, $\beta$-keto esters and the acidic catalyst was allowed to stand for a long time or heated above $150^{\circ} \mathrm{C}$ or the synthetic operations were often complicated involving lengthy work-up procedures. Moreover, in view of environmental concerns, there is a global effort to replace the conventional catalysts by less toxic solid acids that are easily separable from the reaction mixture for reutilization or safe disposal [24].

Hence, it is imperative to develop a convenient, efficient and user-friendly method for the synthesis of nitro substituted 7-hydroxy-4-methyl-2H-chromen-2-one which have antiinflammatory and antibacterial activity by a general method via Pechmann reaction and Using Amberlyst-15 as heterogeneous catalyst

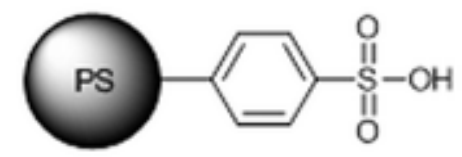

PS= Polystyrene

Figure 2. General formula of Amberlyst-15

It is a macro reticular polystyrene based ion exchange resin with strongly acidic sulfonic group. It serves as an excellent source of strong acid. It can also be used several times. Amberlyst 15, Hammett acidity approximately to one sulfonic acid group [26a].

Amberlyst-15 is of specific interest in this study since it has been reported to be a solid superacid catalyzing a variety of organic conversions and reactions such as esterification, transesterification, Michael addition, aza-Michael addition, Prins cyclization, Friedel-Crafts alkylation, acylation, metal-free hydroarylation, hydroalkylation, halogenation, protection of carbonyls, amines, deprotection of acetals, acetates, Boc-protected amines, cleavage of epoxides, crossed-aldol condensation, synthesis of quinolines, pyrazolines, indolinones, acridines, xanthenes, coumarins, benzopyrans theaspirane, furans, and substituted phosphonates. Applications of this catalyst allow mild and highly selective transformations and synthesis in a facile and environmentally friendly manner [25].

\section{EXPERIMENTAL}

\subsection{Apparatus:}

spectrum NMR proton and carbon device $400 \mathrm{MHz}$ model Bruker by Switzerland company, optical absorption spectrum infrared device model FT-IR-4100 from the Japanese company Jasco, rotary evaporator 4.91 model from the German company Normschiff, thin layer chromatographic of aluminum coated by Silica Gel 60F254 measuring 20 X 20 from the German company Merck, thin layer chromatographic of preparatory glass coated by Silica Gel 60F254 measuring 20 X 20 from the German company Merck.

\subsection{Raw Materials and Reagents:}

Resorcinol, Ethyl Acetoacetate(Sigma-Aldrich \& Merck), Nitric Acid, Sulfuric Acid and the solvents

(99\% by Merck), Amberlyst-15 (99\% by Sigma-Aldrich)

\subsection{Experimental Procedure:}

\section{Synthesis of 7-Hydroxy-4-Methyl Coumarin General Procedure:}

A mixture of resorcinol (1 mmol), ethyl acetoacetate $(1.1 \mathrm{mmol})$ and acid catalyst $(10 \mathrm{~mol} \%)$ were added, then the reaction mixture was stirred in oil bath heated at $110^{\circ} \mathrm{C}$ for the desired time.

The reaction was monitored by thin layer chromatography (T.L.C). After completion of the reaction, mixture was filtered to remove the heterogeneous catalyst, then filtrate was cooled to room temperature, after that, a hot methanol was added to cooled filtrate to result a solid (crude product) that it was filtered and then was recrystallized with ethanol to obtain pure product. The physical data (Melting Point, FT-IR, ${ }^{1} \mathrm{H}-\mathrm{NMR},{ }^{13} \mathrm{C}-\mathrm{NMR}$ ) of these known compounds were found to be identical with those reported in the literature. 


\section{Synthesis of 8-nitro-7-Hydroxy-4-Methyl Coumarin and 6-nitro-7-Hydroxy-4-Methyl Coumarin:}

Procedure: The nitration of 7-hydroxy-4-methyl Coumarin using concentrated nitric acid and sulfuric acid at $5^{\circ} \mathrm{C}$ gave two nitro isomers i.e. 7-hydroxy-4-methyl-8-nitro Coumarin \& 7-hydroxy4-methyl-6-nitro Coumarin. In a conical flask, 7-hydroxy-4-methyl Coumarin (1.2 g) was dissolved in conc. $\mathrm{H}_{2} \mathrm{SO}_{4}$ acid $(10 \mathrm{ml}$.) and then keep the flask in an ice bath. When the temperature inside the flask is below $1{ }^{\circ} \mathrm{C}, 2 \mathrm{ml}$ of nitrating mixture $(0.5 \mathrm{ml}$ of concentrated nitric acid and $1.5 \mathrm{ml}$ of concentrated sulfuric acid) taking care that the temperature does not rise above $10^{\circ} \mathrm{C}$, after the addition was completed, removed the flask from the ice bath and keep it at room temperature for an hour. The flask shook occasionally during this period and then poured with stirring in a beaker containing crushed ice.

The crude product filtered, which is a mixture of 6 and 8 nitro derivatives, and washed with cold water. The crude mixture was transferred in a conical flask containing ethanol and boiled. The residue is 6-nitro-4-methyl-7-hydroxy coumarin.

Concentrated the filtrate, and cooled in an ice bath, 8-nitro derivative soon crystallized out. Recrystallized from ethanol and collect 8-nitro-4-methyl-7-hydroxy coumarin.

\section{Results and Discussion:}

Herein, we report an efficient method for the synthesis and nitration of 7-hydroxy-4-methyl coumarin, reaction of phenols and $\beta$-keto esters in the presence of catalytic amount of Amberlyst-15 afforded the corresponding coumarin derivatives as shown in (Scheme 1).<smiles>CCOC(=O)CC(C)=O</smiles>

Scheme 1. Pechmann condensation reaction of phenols with $\beta$-keto esters to substituted coumarins.

The reactions were clean and affording exclusively coumarins in high yields in a relatively short time. It is an established fact in the literature that pechmann reaction proceeds through transesterification and intramolrcular hydroxyalkylation, followed by dehydration [18, 24]. These three steps are all typical acid catalyzed reactions. Therefore, the outcome of the pechmann reaction depends mechanism for the pechmann condensation of phenols and $\beta$-keto esters by Amberlyst-15 as shown in (Scheme 2).<smiles>CCOC(=O)CC(C)(O)c1ccc(P)cc1O</smiles> 


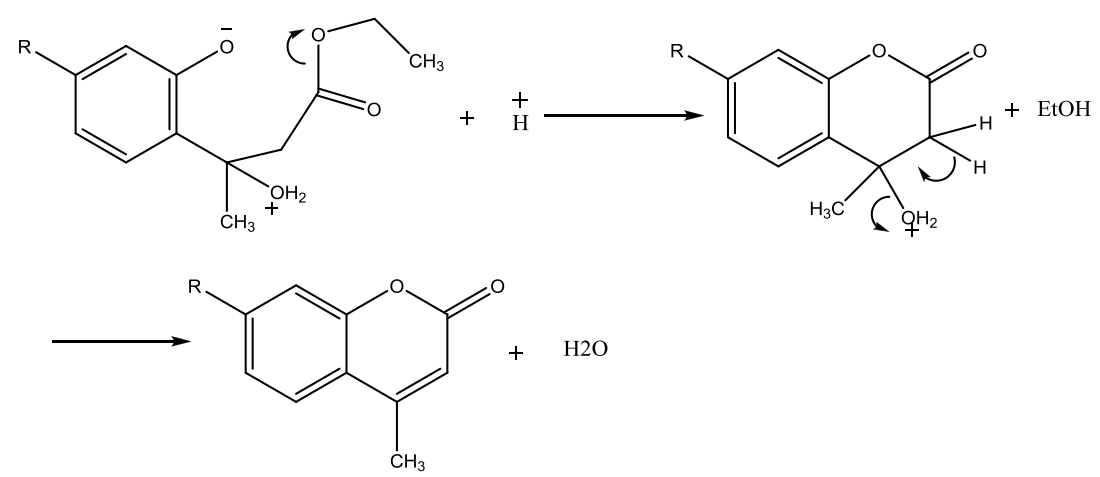

Scheme 2. Plausible mechanism for the pechmann condensation of phenols and $\beta$-keto esters by Amberlyst-15

At first time, for the optimization of the reaction conditions, a mixture of resorcinol and ethyl acetoacetate was investigated as a model and its behavior was studied under a variety of conditions - such as: Temperature, time of reaction, solvents, molar ratio of catalysts and type of catalysts.

The best result was achieved by carrying out the reaction of resorcinol and ethyl acetoacetate (with $1: 1 \mathrm{~mol}$ ratio) in the presence of $(0.2 \mathrm{~g}, 10 \% \mathrm{~mol})$ of Amberlyst-15 at $110^{\circ} \mathrm{C}$ for $100 \mathrm{~min}$. (The reaction mixture was monitored by T.L.C using (ethyl acetate:n-hexane - 2:3) under solvent-free conditions, with an excellent yield (nearly $95 \%$ ) .

The specific impacts of different molar amount of catalyst on the yield did not notice when the amount of catalyst was increased (Table 1):

Table 1. Effect of Amberlyst-15 percentage in Pechmann condensation of resorcinol.

\begin{tabular}{ccc}
\hline Entry & Amount of catalyst (mol.\%) & Yield (\%) \\
\hline 1 & - & Traces \\
2 & 10 & 95 \\
3 & 20 & 96 \\
4 & 30 & 94 \\
5 & 40 & 95 \\
\hline
\end{tabular}

The using of large quantities of Amberlyst-15 did not affect to the preparation of $\mathbf{1}$, so from an economic perspective, it is preferred using the least possible quantity of catalysts.

Then and studying the effect of temperature, synthesis of 1 was carried out at the temperature range of $40^{\circ} \mathrm{C}-150^{\circ} \mathrm{C}$ (Table 2$)$ :

Table 2. Effect of temperature in Pechmann condensation of resorcinol.

\begin{tabular}{ccc}
\hline Entry & Temperature $\left({ }^{\circ} \mathbf{C}\right)$ & Yield (\%) \\
\hline 1 & 40 & 20 \\
2 & 80 & 50 \\
3 & 110 & 95 \\
4 & 130 & 80 \\
5 & 150 & 55 \\
\hline
\end{tabular}

As indicated in Table 2, it is clear that by increasing the temperature until $110^{\circ} \mathrm{C}$ the yield improved from $20 \%$ to $95 \%$, but by increasing the temperature more than $110^{\circ} \mathrm{C}$, the yield was decreased until $55 \%$ at $150^{\circ} \mathrm{C}$, that is probably due to the formation of side products such as chromones, the self-condensation of ethyl acetoacetate, isomerization and cleavage of 7-hydroxy-4methyl Coumarin (Appearance several spots as checked by T.L.C), in addition, the activity of catalyst was decreased at the high temperature because of low thermal stability of the vinyl based polymers [26b], so the temperature $110^{\circ} \mathrm{C}$ is an optimal temperature. 
The time of reaction was optimized 100 min where the reaction was completely finished with the highest yield (monitored by T.L.C), but by increasing the time up to 100 min the yield was decreased, it is probably due to increasing the side products (Appearance several spots as checked by TLC), the results are summarized in Table 3:

Table 3. Effect of the time on Pechmann condensation of resorcinol with ethyl.

\begin{tabular}{ccc}
\hline Entry & Time (min.) & Yield (\%) \\
\hline 1 & 30 & 20 \\
2 & 60 & 30 \\
3 & 100 & 95 \\
4 & 150 & 86 \\
5 & 200 & 75 \\
\hline
\end{tabular}

The effect of several solvent on the yield of coumarin derivatives was studied. As indicated in the previous three tables (table 1,2 and 3), the yield was found to be significantly higher in solventfree conditions. When this result was compared with other solvents. it is found that the non-polar solvents, like toluene, were better than polar solvent, it is due to reduce the formation of hydrogen bonds (inter- and intra-molecular) in the phenol derivatives and also to form an azeotropic mixture (ethanol and water) which was producing during the reaction which facilitates removing them from the reaction media, in addition, that the polar solvents may cause the cleavage [27].

Table 4. Effect of solvent on Pechmann condensation of resorcinol with ethyl acetoacetate.

\begin{tabular}{ccc}
\hline Entry & Solvants & Yield (\%) \\
\hline 1 & Toluene & 92 \\
2 & THF & 70 \\
3 & 1,4-Dioxan & 50 \\
4 & $\mathrm{EtOH}$ & 20 \\
5 & $\mathrm{MeOH}$ & 30 \\
6 & $\mathrm{H} 2 \mathrm{O}$ & 20 \\
7 & - & 95 \\
\hline
\end{tabular}

Several acidic catalysts were examined to compare them with Amberlyst -15 (Table 5). When using homogenous catalysts, it is necessary to use a large quantity of catalysts to have the same yield, but if the same molar percentage was used, the yield will be very low (Table 5, entries 1, 3, 4 and 6). In other hand, when the silica support sulfuric acid catalyst was used (Table 5, entry 2), the yield was not improved, it may return to their high surface polarity which attracts the water molecules that cause poisoning the active sites of catalysts. While nonpolar surface catalyst (Amberlyst-15) (Table 5, entry 5) was stayed active and no poisoning active sites were observed, so the best yield was obtained, in addition, it is easy to isolate the catalyst from the reaction media without any supplementary treatment.

Table 5. Effect of types of catalyst on Pechmann condensation of resorcinol with ethyl acetoacetate.

\begin{tabular}{ccc}
\hline Entry & Catalyst & Yield (\%) \\
\hline 1 & $\mathrm{H}_{2} \mathrm{SO}_{4}$ & 30 \\
2 & $\mathrm{SiO}_{2}-\mathrm{SO}_{4} \mathrm{H}$ & 30 \\
3 & $\mathrm{CH}^{-}-\mathrm{SO}_{3} \mathrm{H}$ & 45 \\
4 & $p$ - $\mathrm{TSA}$ & 50 \\
5 & $\mathrm{Amberlyst}-15$ & 95 \\
6 & $\mathrm{AlCl}_{3}$ & 55 \\
\hline
\end{tabular}


The best result was achieved by caring out the reaction of resorcinol and ethyl acetoacetate (with $1: 1 \mathrm{~mol}$ ratio) in the presence of $0.2 \mathrm{~g}$ of Amberlyst- 15 at $110^{\circ} \mathrm{C}$ under solvent-free conditions and 7-Hydroxy-4-methylcoumarin was obtained in very high yields up to $95 \%$.

To our delight, Amberlyst-15 was successfully recycled at least 5 times (figure.2.) without apparent decrease of activity and selectivity giving a yield at every cycle nearly $95 \%$. After 5 cycles, the color of the Amberlyst-15 changed which is presumably due to the partial deposit of carbonaceous materials but it does not effect on the recyclability of Amberlyst 15.

Then the nitration of 7-hydroxy-4-methyl coumarin (1) using concentrated nitric acid and sulfuric acid at $0^{\circ} \mathrm{C}$ gave 7-hydroxy-4-methyl-8-nitro coumarin (1a) and 7-hydroxy-4- methyl-6nitro coumarin (1b) Scheme 3.
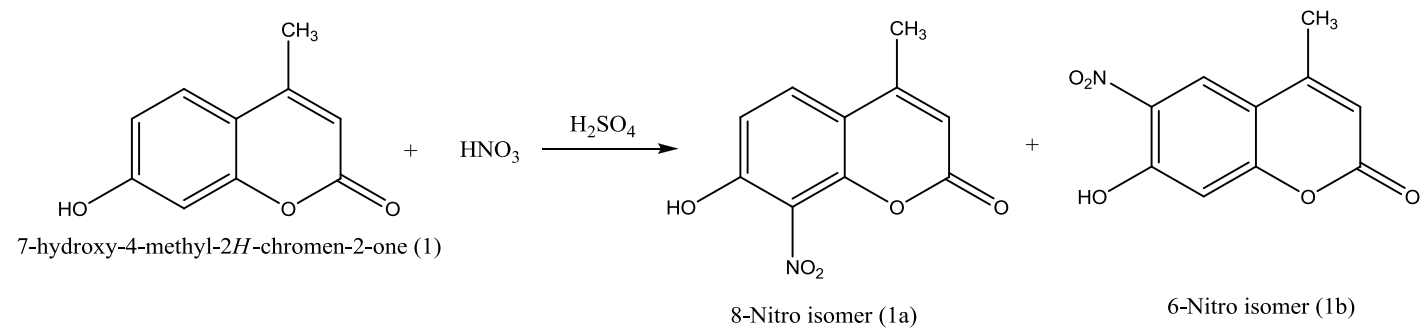

Scheme 3. The nitration of 7-hydroxy-4-methyl coumarin.

The separation of these two isomers was carried out by the difference of solubility in ethanol where the 8-nitro isomer was obtained as a dark yellowish powder (1) whereas the 6-nitro isomer was obtained as a pallid yellowish powder (2).
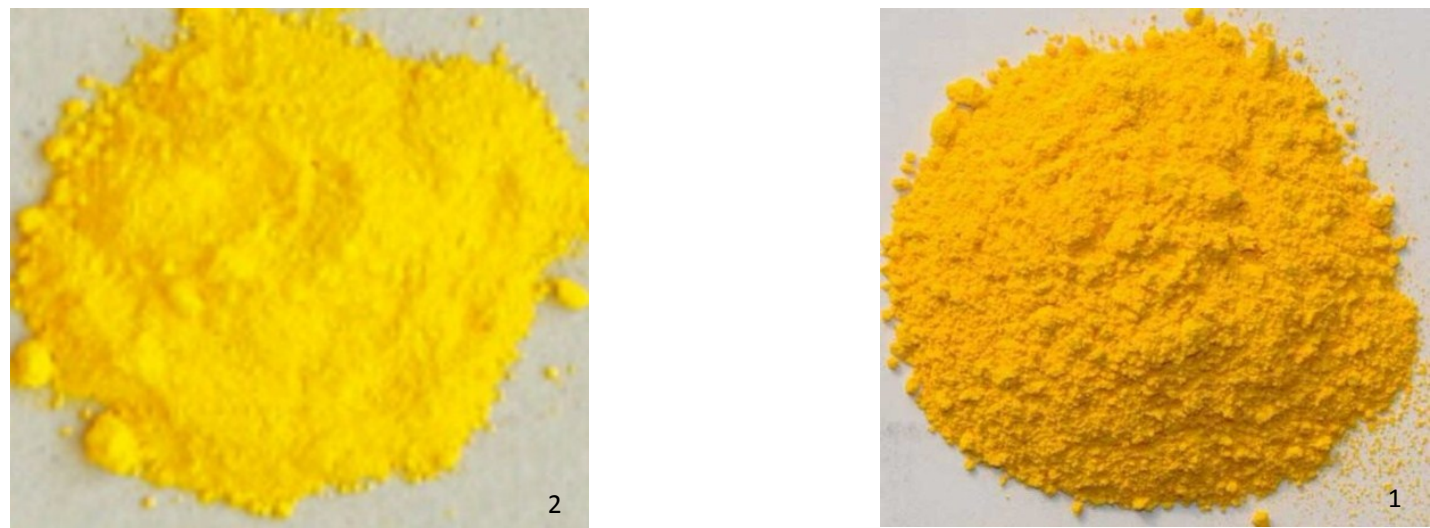

Figure 3. The difference in color between these two isomers.

The ${ }^{1} \mathrm{H}-\mathrm{NMR}$ spectrum $\left(\mathrm{CDCl}_{3}\right)$ of the 8-nitro isomer (1a) showed signals at $2.4 \mathrm{ppm}(3 \mathrm{H}, \mathrm{s}$, $\left.\mathrm{CH}_{3}\right), 6.155 \mathrm{ppm}(1 \mathrm{H}, \mathrm{s}, 3-\mathrm{H})$, at 6.80 and $7.00 \mathrm{ppm}(2 \mathrm{H}, \mathrm{dd}$, aromatic protons, $\mathrm{J}=10 \mathrm{~Hz})$ and at $12.05 \mathrm{ppm}(1 \mathrm{H}, \mathrm{s}, \mathrm{OH})$, whereas the ${ }^{1} \mathrm{H}-\mathrm{NMR}$ spectrum (DMSO-d6) of compounds (1b) showed the same signals except for the aromatic protons at 6.90 and $8.30 \mathrm{ppm}(2 \mathrm{H}$, ss, aromatic protons). Also, the IR spectra of either (1a) or (1b) showed characteristic bands at $1730 \mathrm{~cm}^{-1}$ (lactone $\mathrm{C}=\mathrm{O}$ ) and at $3400 \mathrm{~cm}^{-1}(\mathrm{OH})$.

\section{Characterization of the products:}

7-Hydroxy-4-Methyl Coumarin (entryla) (ethyl acetate:n-hexane, 6:4)

$\operatorname{IR}(\mathrm{KBr}) \quad\left(\mathrm{v}, \mathrm{cm}^{-1}\right): 1680(\mathrm{C}=\mathrm{O}), 2938 \quad\left(\mathrm{C}_{\mathrm{sp} 3}-\mathrm{H}\right), \quad 3116\left(\mathrm{C}_{\mathrm{sp} 2}-\mathrm{H}\right), 1277 \quad(\mathrm{C}-\mathrm{O}), 1518+1455 \quad(\mathrm{C}=\mathrm{C}$ aromatic), $1670\left(\mathrm{C}=\right.$ Calken), ${ }^{1} \mathrm{H}-\mathrm{NMR}$ (DMSO-d6, 400MHz) $(\delta, \mathrm{ppm}): \delta 2.345\left(\mathrm{~s}, 3 \mathrm{H}, \mathrm{CH}_{3}\right)$, 6.113(s, 1H, 3-H), 7.585(d, J=8,8Hz, 1H, 5-H), 6.810(d, J=8,4Hz, 1H, 6-H), $6.702(\mathrm{~s}, 1 \mathrm{H}, 8-\mathrm{H})$, 10.705 (s,OH), ${ }^{13} \mathrm{C}-\mathrm{NMR}(\mathrm{DMSO}-\mathrm{d} 6)$ 8161.11, 111.97, 154.79, 126.53, 112.8, 160.24, 102.13, 18.05, 110.21, 153.46. 
8-nitro-7-Hydroxy-4-Methyl Coumarin (entryla) (dichloromthan:n-hexane, 6:4)

$\operatorname{IR}(\mathrm{KBr})\left(\mathrm{v}, \mathrm{cm}^{-1}\right): 1730(\mathrm{C}=\mathrm{O}), 2925\left(\mathrm{C}_{\mathrm{sp} 3}-\mathrm{H}\right), 3075\left(\mathrm{C}_{\mathrm{sp} 2}-\mathrm{H}\right), 1068(\mathrm{C}-\mathrm{O}), 1535+1626 \quad(\mathrm{C}=\mathrm{C}$ aromatic), ${ }^{1} \mathrm{H}-\mathrm{NMR}\left(\mathrm{CDCl}_{3}\right)(\delta, \mathrm{ppm}): 2.4 \mathrm{ppm}\left(3 \mathrm{H}, \mathrm{s}, \mathrm{CH}_{3}\right), 6.155 \mathrm{ppm}(1 \mathrm{H}, \mathrm{s}, 3-\mathrm{H}), 6.80$ and 7.00 ppm $(2 \mathrm{H}$, dd, aromatic protons $), 11.705(\mathrm{~s}, \mathrm{OH}),{ }^{13} \mathrm{C}-\mathrm{NMR}\left(\mathrm{CDCl}_{3}\right) \delta 158.06,111.96,153.53,18.52$, $145.60,112.02,124.01,128.09,152.76$.

6-nitro-7-Hydroxy-4-Methyl Coumarin (entryla)(dichloromthan:n-hexane, 7:4)

$\operatorname{IR}(\mathrm{KBr})(\mathrm{v}, \mathrm{cm}-\mathrm{l})$ : IR(KBr) (v, cm-1):1730 (C=O), $2925\left(\mathrm{C}_{\mathrm{sp} 3}-\mathrm{H}\right), 3075\left(\mathrm{C}_{\mathrm{sp} 2}-\mathrm{H}\right), 1068(\mathrm{C}-\mathrm{O}), 1535+$ $1626\left(\mathrm{C}=\right.$ Caromatic), ${ }^{1} \mathrm{H}-\mathrm{NMR}(\mathrm{DMSO}-\mathrm{d} 6,400 \mathrm{MHz})(\delta, \mathrm{ppm}): 2.4 \mathrm{ppm}\left(3 \mathrm{H}, \mathrm{s}, \mathrm{CH}_{3}\right), 6.155 \mathrm{ppm}$ $(1 \mathrm{H}, \mathrm{s}, 3-\mathrm{H}), 6.90$ and $8.30(2 \mathrm{H}$, ss, aromatic protons $), 11.00(\mathrm{~s}, \mathrm{OH}),{ }^{13} \mathrm{C}-\mathrm{NMR}$ (DMSO-d6, $400 \mathrm{MHz}) \delta 132.86,123.21,105.03,156.53,159.04,152.76,112.02,18.52,153.53,111.96$

\section{Conclusion:}

In conclusion, we have developed a simple and efficient synthesis of substituted coumarins via Pechmann condensations using Amberlyst-15 catalyst under solvent-free conditions. Moreover the low cost of the catalyst comparison with other traditional catalysts such as sulfuric acid and by reused several times, solvent-free condition as shown in table.4, low toxicity of the catalyst, fast reaction times not more than 150 minutes, simple experimental procedure, recyclability of the catalyst and high yields of the products are the advantages.

\section{Acknowledgement:}

The authors express their thanks to central laboratory in department of chemistry, AL Baath University, faculty of sciences, for their assistance during the work.

\section{References:}

[1] R. I. Al-Bayati, A. A. Hussain Al-Amiery, Y. K. Al-Majedy, Design, synthesis and bioassay of novel coumarins, J. African Pure and Applied Chemistry. 4 (2010) 74-86.

[2] G. Cravotto, G. M. Nano, G. Palmisano, S. Tagliapietra, An asymmetric approach to coumarin anticoagulants via hetero-Diels-Alder cycloaddition, J. Tetrahedron: Asymmetry. 12 (2001) 707-709.

[3] O. Kayser, H. Kolodziej, Antibacterial Activity of Extracts and Constituents of Pelargonium sidoides and Pelargonium reniforme, J. Planta Med. 63 (1997) 508-510.

[4] C. J. Wang, Y. J. Hsieh, C. Y. Chu, Y. L. Lin, T. H. Tseng, Inhibition of cell cycle progression in human leukemia HL-60 cells by esculetin, J. Cancer Lett. 183 (2002) 163-168.

[5] G. J. Fan, W. Mar, M. K. Park, E. Wook Choi, K. Kim, S. Kim, A novel class of inhibitors for steroid $5 \alpha$-Reductase: synthesis and evaluation of umbelliferone derivatives, J. Bioorg. Med. Chem. Lett. 11 (2001) 2361-2363.

[6] S. Kirkiacharian, D. T. Thuy, S. Sicsic, R. Bakhchinian, R. Kurkjian, T. Tonnaire, Structureactivity relationships of some 3-substituted-4-hydroxycoumarins as HIV-1 protease inhibitors, J. Il Farmaco. 57 (2002) 703-708.

[7] S. M. Sethna, N. M. Shah, The Chemistry of Coumarins, J. Chem. Rev. 36 (1945) 1-62.

[8] R. S. Overmann et.al, Studies on The Hemorrhagic Sweet Clover Disease: XIII. Anticoagulant Activity and Structure in The 4-Hydroxycoumarin Group, J. Biol.Chem. 5 (1944) 153-158.

[9] E. Werner, XXXVIII.-Researches on chrom-organic acids, J. Chem. Soc. Trans. 51(1887) 383389.

[10] J. D. Hepwarh, A. J. Boulton, A. McKillop, Comprehensive Heterocyclic Chemistry Pergamon, Oxford. 3 (1984) 881.

[11] R. S. Mali, V. J. Yadav, Convenient Synthesis of Naturally Occurring Coumarins, (2-Oxo-2Hbenzopyrans) and 4-Methylcoumarins (4-Methyl-2-oxo-2H-benzopyrans), J. Synthesis. 12 (1977) 464-465.

[12] R. L. Shriner, The Reformatsky Reaction, J. Organic Reactions. 1 (1942) 1-37. 
[13] S. E. Drewes, N.D. Emslie, N. Karodia, G. Loizou, Synthesis of Useful Intermediates from the Claisen-Rearrangement of $\alpha$-Hydroxy Alkyl Acrylate Precursors, J. Synth.Commun. 20 (1990) 1437-1443.

[14]G. Speranza, A.D. Meo, S. Zanzola, G. Fontanna, P. Manitto, Uncatalyzed Reaction of Phenols and Naphthols with Methyl Cinnamates. A Simple Synthesis of 4-Arylchroman-2-ones and 1Arylbenzo[f]chroman-3-ones, J. Synthesis. (1997) 931-936.

[15] V. H. Pechmann, C. Duisberg, Neue Bildungsweise der Cumarine Synthese des Daphnetins, J. Chem. Ber. 17 (1884) 929-936.

[16] S. Trenor, A. Shultz, B. Love, T. Long, Coumarins in Polymers: From Light Harvesting to Photo-Cross-Linkable Tissue Scaffolds, Chemical Reviews. 104 (2004) 3059-3078.

[17] J. Singh, J. Kaur, S. Nayyar, G. Kad, Highly Efficient and Single Step Synthesis of 4Phenylcoumarins and 3,4-Dihydro-4-phenylcoumarins Over Montmorillonite K-10 Clay, Under Microwave Irradiation†, J. Chem. Res. 5 (1998) 280-281.

[18] A. Khandekar, B. Khadilkar, Pechmann Reaction in Chloroaluminate Ionic Liquid, J. Synlett. 1 (2002) 0152-0154.

[19] A. Ramani, B. Chanda, S. Velu, S. Sivasanker, One-pot synthesis of coumarins, J. Green Chemistry, 1 (1999) 163-165.

[20] D. Subhas Bose, A. Rudradas, M. Hari Babu, The indium (III) chloride-catalyzed von Pechmann reaction: a simple and effective procedure for the synthesis of 4-substituted coumarins, J. Tetrahedron Letters, 43 (2002) 9195-9197.

[21] D. Bogdał, Coumarins: Fast Synthesis by Knoevenagel Condensation under Microwave Irradiation, J. Chem. Res. 8 (1998) 468-469.

[22] A. Hoefnagel, E. Gunnewegh, R. Downing, H. van Bekkum, Synthesis of 7-hydroxycoumarins catalysed by solid acid catalysts, J. Chemical Society, Chemical Communications, 2 (1995) 225-226.

[23] Y. Rao, S. Kulkarni, M. Subrahmanyam, A. Rao, A novel acylative cyclization reaction of phenol over modified Y zeolites, J. the Chemical Society, Chemical Communications. 18 (1993) 1456-1457.

[24] A. Hoefnagel, E. Gunnewegh, R. Downing, H. van Bekkum, Synthesis of 7-hydroxycoumarins catalysed by solid acid catalysts, J. the Chemical Society, Chemical Communications. 2 (1995) 225-226.

[25] R. Pal, T. Sarkar, SH. Khashobis, Amberlyst-15-in organig synthesis, J. arkivoc. 1 (2012) 570609.

[26] K. Tanaka, F. Toda, Solvent-Free Organic Synthesis, J. Chemical Reviews. 100 (2000) 10251074.

[27] A. Olah, G.K.S. Prakash, A. Molnar, J. Sommer in Superacid Chemistry, John Wiley \& Sons, Inc.:Hoboken, NJ, 2009.

[28] R. Sabou, W. Hoelderich, D. Ramprasad, R. Weinand, Synthesis of 7-hydroxy-4methylcoumarin via the Pechmann reaction with Amberlyst ion-exchange resins as catalysts, J. Catalysis. 232 (2005) 34-37. 